\title{
Hipoalbuminemia praoperasi pasien kanker kolorektal terhadap risiko komplikasi pascaoperasi dan lama rawat inap
}

\author{
Preoperative hypoalbumin colorectal cancer inpatients to risk for postoperative complications and length of stay
}

Yohanes Benny ${ }^{1}$, Teguh Aryandono², Susetyowati ${ }^{2}$

\begin{abstract}
Background: Malnutrition is most commonly found in gastrointestinal cancer that affects the result of operation. Albumin serum is an effective and simple way of assessing risk which is associated with malnutrition intensity so that it is generally used as prognostic index for the development of the incidence of colorectal cancer postoperative complications.

Objective: To identify effect of preoperative hypoalbumin to the incidence of postoperative complications and length of stay of colorectal cancer inpatients.

Method: The study used quantitative approach with non concurrent cohort (retrospective analysis) design. Population were patients diagnosed having colorectal cancer who would undergo operation at Kasih Ibu, Dr. Oen, and Panti Waluyo Hospital of Surakarta. Data analysis used Chi-Square test and logistic regression.

Results: Hypoalbumin, either based on admission or pre operation, was significant risk factor for the incidence of post operative complications in colorectal cancer patients as well as age and American Society of Anesthesiologist Physical Status Classification (ASA) status. The result of multivariate analysis showed age of 20-59 years (OR=2), hypoalbumin based on admission (2.1 times) and preoperation (1.9 times) were risk factors for the incidence of postoperative complication (infection). ASA status III-IV had risk 2.8 times for the incidence of postoperative sepsis complications and 3.7 times for mortality than ASA status I-II. Status of hypoalbumin did not influence total length of stay or postoperative length of stay but age influenced postoperative length of stay.

Conclusion: Hypoalbumin influenced the incidence of postoperative complications in colorectal cancer patients, particularly infection complication; whereas factors of age and ASA status were external factors strongly influenced. Hypoalbumin did not influence length of stay. Age was external factor that strongly influenced postoperative length of stay.
\end{abstract}

KEY WORDS: hypoalbumin, postoperative complications, length of stay, age, ASA status, cancer

\begin{abstract}
ABSTRAK
Latar belakang: Malnutrisi merupakan masalah yang paling sering terjadi pada kanker gastrointestinal dan berdampak pada hasil operasi. Serum albumin merupakan cara yang baik dan sederhana dalam memprediksi dan memiliki hubungan yang baik dengan derajat malnutrisi sehingga sering digunakan sebagai indeks prognostik untuk perkembangan terjadinya komplikasi pascaoperasi kanker kolorektal.

Tujuan: Mengetahui pengaruh hipoalbumin praoperasi terhadap kejadian komplikasi pascaoperasi dan lama rawat inap pasien kanker kolorektal.

Metode: Penelitian ini menggunakan pendekatan kuantitatif dengan rancangan penelitian non-concurrent cohort (retrospective analysis) pada pasien yang terdiagnosa kanker kolorektal yang akan menjalani operasi di Rumah Sakit Kasih Ibu Surakarta, Rumah Sakit Dr. Oen Surakarta, dan Rumah Sakit Panti Waluyo. Analisa data menggunakan uji Chi-Square dan regresi logistik berganda.

Hasil: Hipoalbumin berdasarkan kadar albumin saat admisi maupun kadar albumin praoperasi merupakan faktor risiko signifikan terjadinya komplikasi pascaoperasi pasien kanker kolorektal. Demikian juga dengan faktor usia dan status ASA. Analisa multivariat menunjukkan bahwa usia 20-59 tahun (OR=2), hipoalbumin berdasarkan kadar albumin admisi $(O R=2,1)$, dan kadar albumin praoperasi $(O R=1,9)$ berisiko terhadap terjadinya komplikasi pascaoperasi (infeksi). Status ASA III-IV mempunyai risiko 2,8 kali untuk terjadinya komplikasi sepsis pascaoperasi dan 3,7 kali terhadap kematian dibandingkan status ASA I-II. Status hipoalbumin tidak mempengaruhi lama rawat inap total maupun lama rawat inap pascaoperasi melainkan faktor usia yang berpengaruh terhadap lama rawat inap pascaoperasi.

Simpulan: Hipoalbumin mempengaruhi terjadinya komplikasi pascaoperasi pasien kanker kolorektal terutama komplikasi infeksi sedangkan faktor usia dan status ASA merupakan faktor luar yang berpengaruh kuat. Hipoalbumin tidak mempengaruhi lama rawat inap, meskipun faktor usia merupakan faktor luar yang berpengaruh kuat terhadap lama rawat inap pascaoperasi.
\end{abstract}

KATA KUNCI: hipoalbumin, komplikasi pasca operasi, lama rawat inap, usia, status ASA, kanker

\footnotetext{
${ }^{1}$ Korespondensi: Rumah Sakit Kasih Ibu Surakarta, Jl. Slamet Riyadi 404, Laweyan, Surakarta

${ }^{2}$ Fakultas Kedokteran Universitas Gadjah Mada, Jl. Farmako, Sekip Utara, Yogyakarta 55281

${ }^{3}$ Program Studi Gizi Kesehatan, Fakultas Kedokteran Universitas Gadjah Mada, Jl. Farmako, Sekip Utara, Yogyakarta 55281, e-mail: susetyowati2000@ yahoo.com
} 


\section{PENDAHULUAN}

Kanker merupakan masalah kesehatan paling besar di Amerika (US) dan di beberapa negara lainnya di dunia. Organisasi Kesehatan Dunia (WHO) memperkirakan pada tahun 2020, lebih dari lima belas juta orang akan menderita kanker dan sepuluh juta akan meninggal karena kanker setiap tahun (1). Kanker kolorektal merupakan masalah kesehatan utama di negara-negara berkembang (2).

Pasien kanker kolorektal memiliki risiko terhadap malnutrisi yang diakibatkan adanya peningkatan metabolisme yang disebabkan oleh kanker, penurunan asupan makanan, dan cachexia (3). Malnutrisi dan cachexia pada pasien kanker kolorektal merupakan masalah yang sering terjadi karena tumor, respon pasien terhadap tumor, dan terapi anti kanker. Malnutrisi sering dihubungkan dengan sejumlah konsekuensi klinis, misalnya penurunan kualitas hidup, penurunan respon terhadap pengobatan, peningkatan risiko kemoterapi, peningkatan toksisitas, dan penurunan angka keselamatan dari kanker (1).

Sementara itu, serum albumin merupakan cara yang bagus dan sederhana dalam menghitung risiko dan memiliki hubungan yang baik dengan derajat malnutrisi. Kadar serum albumin yang rendah berhubungan dengan peningkatan morbiditas dan mortalitas pada pasienpasien yang menjalani operasi (3-5). Di rumah sakit, serum albumin dihubungkan dengan laporan mengenai tingkat kematian di rumah sakit, lama rawat inap, dan infeksi nosokomial. Serum albumin juga digunakan sebagai alat untuk menentukan prognosa dari beberapa kanker, misalnya kanker paru-paru, kanker pankreas, kanker lambung, kanker kolorektal, dan kanker payudara (1). Bahkan, beberapa penelitian menyatakan kadar serum albumin di bawah normal dapat digunakan untuk memperkirakan hasil (outcome) dari penyakit kanker yang diderita terhadap kelompok-kelompok pasien kanker (6).

Hipoalbumin sering dihubungkan dengan lamanya pemulihan fungsi usus dan komplikasi pascaoperasi kanker kolon atau operasi gastrointestinal dan kadar albumin merefleksikan status gizi pada pasien yang menjalani rawat inap dalam jangka waktu lama $(3,4)$. Persentase komplikasi pascaoperasi kanker kolorektal pada kelompok pasien usia lanjut dengan status gizi yang lebih buruk dibandingkan kelompok pasien usia muda, tidak lebih tinggi secara signifikan sehingga dapat diambil kesimpulan bahwa hipoproteinemia dan hipoalbuminemia tidak mempengaruhi pemulihan pascaoperasi pasien kanker kolorektal meskipun pasien mendapatkan perawatan yang optimal pada waktu praoperasi (7). Informasi efek hipoalbumin terhadap perkembangan komplikasi pascaoperasi kanker kolorektal masih sangat sedikit dan hasilnya masih bersifat kontroversial (3). Latar belakang tersebut menunjukkan bahwa masih adanya hasil penelitian yang bersifat kontroversial. Oleh karena itu, perlu penelitian tentang pengaruh kadar albumin yang rendah pada pasien kanker kolorektal ketika sebelum operasi terhadap risiko komplikasi pascaoperasi dan lamanya pasien menjalani proses rawat inap.

\section{BAHAN DAN METODE}

Penelitian ini merupakan penelitian analitik dengan rancangan non-concurrent cohort (retrospective analysis) yang dilaksanakan pada bulan Januari sampai Maret 2012. Populasi dalam penelitian ini adalah pasien yang terdiagnosa kanker kolorektal (kanker kolon dan rektal) yang akan menjalani operasi di Rumah Sakit Kasih Ibu Surakarta, Rumah Sakit Dr. Oen Surakarta, dan Rumah Sakit Panti Waluyo Surakarta. Kriteria inklusi adalah pasien kanker kolorektal yang menjalani operasi untuk pertama kalinya dan berusia lebih dari atau sama dengan 18 tahun ( $\geq 18$ tahun), pasien operasi elektif, serta mendapatkan pemeriksaan laboratorium praoperasi albumin. Kriteria eksklusi adalah memiliki riwayat penyakit ginjal, nefropati diabetik, memiliki riwayat operasi ulang kanker kolorektal, memiliki riwayat operasi karena obstruksi usus, dan pasien kanker kolorektal melakukan penghentian rawat inap atas permintaan pasien atau keluarga pasien sebelum atau sesudah pasien menjalani operasi.

Subjek penelitian dibagi menjadi dua kelompok berdasarkan kadar albumin admisi yaitu hipoalbumin (albumin $<3,5 \mathrm{~g} / \mathrm{dL}$ ) dan pasien yang tidak mengalami hipoalbumin (albumin $\geq 3,5 \mathrm{~g} / \mathrm{dL}$ ). Jumlah sampel penelitian dihitung menggunakan rumus besaran sampel pengujian hipotesis risiko relatif populasi dengan proporsi kejadian komplikasi pascaoperasi pada pasien kanker kolorektal hipoalbumin $\left(\mathrm{P}_{2}\right)$ sebanyak $40 \%$, tingkat kepercayaan $\left(Z_{1}\right.$ $\left.{ }_{-\alpha / 2}\right)$ sebesar $95 \%$, dan confidence interval $\left(Z_{1-\beta}\right)$ sebesar $90 \%$ sehingga diperoleh besar sampel minimal untuk masing-masing kelompok sebesar 108 sampel (8). Secara keseluruhan, sampel data penelitian sebesar 216 pasien yang dibagi menjadi dua kelompok yaitu kelompok pasien hipoalbumin dan kelompok pasien non-hipoalbumin.

Variabel yang diteliti dalam penelitian ini terdiri dari variabel dependen (terikat) yaitu komplikasi pascaoperasi (infeksi, leakage, perdarahan, sepsis, kematian) dan lama rawat inap (length of stay / LOS). Variabel independen (bebas) adalah kadar albumin admisi dan kadar pretreatment albumin atau hipoalbumin praoperasi sedangkan variabel luar adalah umur, anemia, dan status American Society of Anesthesiologist Physical Status Classification (status ASA) untuk melihat pengaruhnya sebagai confounding factor.

Komplikasi pascaoperasi dalam penelitian ini terdiri dari infeksi yang ditandai adanya leukositosis (leukosit untuk orang dewasa $>11.000 / \mathrm{mm}^{3}$ ) atau leukopenia (leukosit untuk orang dewasa $<4.000 / \mathrm{mm}^{3}$ ) (9) dan demam (suhu badan $>37^{\circ} \mathrm{C}$ ); leakage yaitu adanya kebocoran 
anastomosis / fistula berdasarkan penilaian cairan pada selang drain yang terpasang (10); perdarahan berdasarkan penilaian klinis abnormalitas jumlah denyut jantung, tekanan darah yang rendah, pemeriksaan hemoglobin (Hb) dan hematokrit oleh dokter bedah (10); sepsis berdasarkan adanya proses infeksi serta tanda-tanda klinis sepsis; dan kematian. Komplikasi pascaoperasi dikelompokkan menjadi dua, yaitu dikatakan pasien mengalami komplikasi pascaoperasi apabila pasien mengalami salah satu atau lebih komplikasi pascaoperasi (infeksi, leakage, perdarahan, sepsis, dan kematian) dan pasien tidak mengalami komplikasi pascaoperasi. Lama rawat inap dihitung sejak pasien kanker kolorektal masuk rawat inap pertama kali sampai pasien diperbolehkan menjalani rawat jalan (seizin dari dokter yang merawat) atau pasien meninggal. Lama rawat inap total dan lama rawat inap pascaoperasi dikategorikan menjadi pendek ( $\leq$ 9 hari) dan panjang (> 9 hari) (11).

Pemeriksaan kadar serum albumin dilakukan sebanyak dua kali, yaitu hasil pemeriksaan kadar albumin pada saat menjalani rawat inap pertama kali (admisi) dan hasil pemeriksaan kadar albumin terakhir (pre-treatment albumin) sebelum menjalani operasi elektif (proses operasi yang melewati prosedur penjadwalan terlebih dahulu) setelah pasien kanker kolorektal menjalani perawatan dan mendapatkan terapi untuk menaikkan kadar serum albumin supaya layak operasi. Dalam hal ini, kadar serum albumin kurang dari 3,5 g/dL dikategorikan mengalami hipoalbumin (1). Sementara itu, kadar $\mathrm{Hb}$ pasien kanker kolorektal yang diperiksa sebelum menjalani operasi, dikategorikan kurang jika kadar $\mathrm{Hb}$ pada laki-laki kurang dari 13,5 g/dL dan pada wanita kurang dari $12 \mathrm{~g} / \mathrm{dL}$ (12).

Status American Society of Anesthesiologist Physical Status Classification (ASA) adalah standar untuk menentukan risiko yang berkaitan dengan anestesi dan operasi. Kategori ASA terdiri dari ASA I: Pasien sehat, tanpa ada penyakit organik, biokimia atau penyakit psikiatrik; ASA II: Pasien dengan penyakit sistemik ringan, tidak berdampak pada aktivitas sehari-hari, diperkirakan tidak ada dampak pada tindakan anestesi dan operasi; ASA III: Pasien dengan penyakit sistemik signifikan atau berat yang membatasi aktivitas sehari-hari, mungkin berdampak pada tindakan anestesi dan operasi; ASA IV: Pasien dengan penyakit berat yang mengancam keselamatan jiwa atau membutuhkan terapi intensif yang sangat membatasi aktivitas sehari-hari, berdampak besar pada tindakan anestesi dan operasi; ASA V: Pasien dalam kondisi hampir meninggal atau dapat diperkirakan akan meninggal dalam waktu 24 jam kemudian dengan atau tanpa tindakan operasi; ASA VI: Pasien donor organ dalam kondisi mati otak (13).

Instrumen penelitian yang digunakan dalam penelitian ini adalah data rekam medis pasien kanker kolorektal yang akan menjalani operasi elektif di Rumah
Sakit Kasih Ibu Surakarta, Rumah Sakit Dr. Oen Surakarta, dan Rumah Sakit Panti Waluyo Surakarta. Analisis bivariat dilakukan dengan menggunakan uji statistik Chi-Square untuk melihat pengaruh variabel bebas terhadap variabel terikat sedangkan analisis multivariat dengan multiple regression logistic (regresi logistik berganda) untuk mengetahui faktor yang paling dominan antara variabel bebas dan terikat dengan mengikutkan variabel lain. Penelitian ini dilaksanakan setelah mendapatkan surat ethical clearance penelitian dari Komite Etika Fakultas Kedokteran Universitas Gadjah Mada.

\section{HASIL}

Karakteristik subjek penelitian berdasarkan kadar albumin admisi dapat diketahui bahwa dari 108 orang dengan status hipoalbumin, sebagian besar $(62,64 \%)$ berumur 20-59 tahun dan ditetapkan status ASA I - II. Sementara itu, berdasarkan karakteristik kadar $\mathrm{Hb}$ diperoleh 26 orang (50\%) mengalami anemia dan 82 orang (50\%) tidak mengalami anemia. Hasil analisis menunjukkan adanya hubungan yang bermakna antara usia dan status ASA terhadap kadar albumin admisi $(p=0,002$ dan $p=0,016)$. Setelah kadar albumin praoperasi diperiksa kembali, dapat diketahui bahwa jumlah pasien dengan status hipoalbumin menjadi 96 orang yang sebagian besar (56,04\%) berumur 20-59 tahun dan karakteristik status ASA ditetapkan ASA I - II. Selain itu, menurut kadar $\mathrm{Hb}$ diperoleh 22 orang (42,31\%) mengalami anemia dan 74 orang $(45,12 \%)$ tidak mengalami anemia. Hasil analisis menunjukkan hubungan yang bermakna hanya pada usia terhadap kadar albumin praoperasi $(p=0,003)$ (Tabel 1).

Berdasarkan Tabel 2 dapat diketahui hubungan variabel-variabel dengan kejadian komplikasi pascaoperasi melalui uji Chi-Square yang menunjukkan hubungan bermakna $(p<0,05)$ kecuali variabel kadar $\mathrm{Hb}$ dengan kejadian komplikasi pascaoperasi yang tidak menunjukkan hubungan bermakna ( $p>0,05)$.

Pasien kanker kolorektal dengan status hipoalbumin, menjalani lama rawat inap total lebih lama dibandingkan pasien kanker kolorektal dengan status albumin normal $(16,99 \pm 8,29$ hari vs. $14,43 \pm 8,13$ hari; $p=0,045)$. Demikian juga dengan lama rawat inap pascaoperasi pada pasien kanker kolorektal dengan status hipoalbumin yang lebih lama dibandingkan pasien kanker kolorektal dengan status albumin normal, tetapi hasil analisis tidak bermakna $(12,66 \pm 7,13$ hari vs. $11,52 \pm 7,63$ hari; $p=0,126)$. Berdasarkan Tabel 3 dapat diketahui hubungan beberapa variabel dengan lama rawat inap total dan lama rawat inap pascaoperasi melalui uji Chi-Square yang tidak menunjukkan hubungan bermakna $(p>0,05)$. Sementara itu, hanya variabel usia yang menunjukkan hubungan bermakna dengan lama rawat inap pascaoperasi $(p<0,05)$. 
Tabel 1. Karakteristik subjek penelitian berdasarkan kadar albumin

\begin{tabular}{|c|c|c|c|c|c|c|c|c|}
\hline \multirow[b]{2}{*}{ Variabel } & \multicolumn{4}{|c|}{ Kadar albumin admisi (n, \%) } & \multicolumn{4}{|c|}{ Kadar albumin praoperasi (n, \%) } \\
\hline & $\begin{array}{c}\text { Hipoalbumin } \\
n=108\end{array}$ & $\begin{array}{c}\text { Normal } \\
n=108\end{array}$ & $\chi^{2}$ & $\mathbf{p}$ & $\begin{array}{c}\text { Hipoalbumin } \\
n=96\end{array}$ & $\begin{array}{c}\text { Normal } \\
n=120\end{array}$ & $\chi^{2}$ & $\mathbf{p}$ \\
\hline \multicolumn{9}{|l|}{ Usia (tahun) } \\
\hline $20-59$ & $57(62,64)$ & $34(37,36)$ & 10,045 & $0,002^{*}$ & $51(56,04)$ & 40 & 8,568 & $0,003^{*}$ \\
\hline$\geq 60$ & $51(40,80)$ & $74(59,20)$ & & & $45(36,00)$ & 80 & & \\
\hline \multicolumn{9}{|l|}{ ASA } \\
\hline I - II & $60(43,80)$ & $77(56,20)$ & 5,767 & $0,016^{*}$ & $54(39,42)$ & 83 & 3,835 & 0,050 \\
\hline III - IV & $48(60,76)$ & $31(39,24)$ & & & $42(53,16)$ & 37 & & \\
\hline \multicolumn{9}{|l|}{ Hemoglobin } \\
\hline Anemia & $26(50)$ & $26(50)$ & 0,000 & 1,000 & $22(42,31)$ & $30(57,69)$ & 0,126 & 0,722 \\
\hline Normal & $82(50)$ & $82(50)$ & & & $74(45,12)$ & $90(54,88)$ & & \\
\hline
\end{tabular}

Keterangan: * bermakna $(p<0,05) ; A S A=$ American Society of Anesthesiologist Physical Status Classification

Tabel 2. Distribusi variabel berdasarkan komplikasi pascaoperasi

\begin{tabular}{|c|c|c|c|c|c|c|c|c|}
\hline \multirow{3}{*}{ Variabel } & \multicolumn{6}{|c|}{ Komplikasi } & \multirow{3}{*}{$\chi^{2}$} & \multirow{3}{*}{$\mathbf{p}$} \\
\hline & \multicolumn{2}{|c|}{ Komplikasi } & \multicolumn{2}{|c|}{ Non-komplikasi } & \multicolumn{2}{|c|}{ Total } & & \\
\hline & $\mathbf{n}$ & $\%$ & $\mathbf{n}$ & $\%$ & $\mathbf{n}$ & $\%$ & & \\
\hline \multicolumn{9}{|l|}{ Albumin admisi } \\
\hline Hipoalbumin & 48 & 44,44 & 60 & 55,56 & 108 & 100 & 10,946 & $0,001^{*}$ \\
\hline Non-hipoalbumin & 25 & 23,15 & 83 & 76,85 & 108 & 100 & & \\
\hline \multicolumn{9}{|l|}{ Albumin praoperasi } \\
\hline Hipoalbumin & 43 & 44,79 & 53 & 55,21 & 96 & 100 & 9,337 & $0,002^{*}$ \\
\hline Non-hipoalbumin & 30 & 25,00 & 90 & 75,00 & 120 & 100 & & \\
\hline \multicolumn{9}{|l|}{ Usia (tahun) } \\
\hline $20-59$ & 44 & 48,35 & 47 & 51,65 & 91 & 100 & 14,890 & $0,000^{*}$ \\
\hline$\geq 60$ & 29 & 23,20 & 96 & 76,80 & 125 & 100 & & \\
\hline \multicolumn{9}{|l|}{ ASA } \\
\hline I - II & 39 & 28,47 & 98 & 71,53 & 137 & 100 & 4,755 & $0,029 *$ \\
\hline III - IV & 34 & 43,04 & 45 & 56,96 & 79 & 100 & & \\
\hline \multicolumn{9}{|l|}{ Hemoglobin } \\
\hline Anemia & 17 & 32,69 & 35 & 67,31 & 52 & 100 & 0,037 & 0,847 \\
\hline Normal & 56 & 34,15 & 108 & 65,85 & 164 & 100 & & \\
\hline
\end{tabular}

Keterangan: * bermakna $(p<0,05) ; A S A=$ American Society of Anesthesiologist Physical Status Classification

Tabel 3. Distribusi variabel berdasarkan LOS total dan LOS pascaoperasi

\begin{tabular}{|c|c|c|c|c|c|c|c|c|}
\hline \multirow[b]{2}{*}{ Variabel } & \multicolumn{4}{|c|}{ LOS total } & \multicolumn{4}{|c|}{ LOS pascaoperasi } \\
\hline & $\begin{array}{c}\text { Panjang } \\
\mathrm{n}(\%)\end{array}$ & $\begin{array}{c}\text { Pendek } \\
\text { n (\%) }\end{array}$ & $\chi^{2}$ & $\mathbf{p}$ & $\begin{array}{c}\text { Panjang } \\
\mathrm{n}(\%)\end{array}$ & $\begin{array}{c}\text { Pendek } \\
\text { n (\%) }\end{array}$ & $\chi^{2}$ & $\mathbf{p}$ \\
\hline \multicolumn{9}{|l|}{ Albumin admisi } \\
\hline Hipoalbumin & $91(84,26)$ & $17(15,74)$ & 0,000 & 1,000 & $66(61,11)$ & $42(38,89)$ & 0,930 & 0,335 \\
\hline Non-hipoalbumin & $91(84,26)$ & $17(15,74)$ & & & $59(54,63)$ & $49(45,37)$ & & \\
\hline \multicolumn{9}{|l|}{ Albumin praoperasi } \\
\hline Hipoalbumin & $81(84,38)$ & $15(15,63)$ & 0,002 & 0,967 & $61(63,54)$ & $35(36,46)$ & 2,279 & 0,131 \\
\hline Non-hipoalbumin & $101(84,17)$ & $19(15,83)$ & & & $64(53,33)$ & $56(46,67)$ & & \\
\hline \multicolumn{9}{|l|}{ Usia (tahun) } \\
\hline $20-59$ & $78(85,71)$ & $13(14,29)$ & 0,251 & 0,616 & $60(65,93)$ & $31(34,07)$ & 4,194 & $0,041^{*}$ \\
\hline$\geq 60$ & $104(83,2)$ & $21(16,8)$ & & & $65(52)$ & $60(48)$ & & \\
\hline \multicolumn{9}{|l|}{ ASA } \\
\hline I - II & $116(84,67)$ & $21(15,33)$ & 0,048 & 0,827 & $80(58,39)$ & $57(41,61)$ & 0,042 & 0,837 \\
\hline III - IV & $66(83,54)$ & $13(16,46)$ & & & $45(56,96)$ & $34(43,04)$ & & \\
\hline \multicolumn{9}{|l|}{ Hemoglobin } \\
\hline Anemia & $44(84,62)$ & $8(15,38)$ & 0,007 & 0,936 & $32(61,54)$ & $20(38,46)$ & 0,378 & 0,539 \\
\hline Normal & $138(84,15)$ & $26(15,85)$ & & & $93(56,71)$ & $71(43,29)$ & & \\
\hline
\end{tabular}

Keterangan: * bermakna $(p<0,05)$; LOS = length of stay / lama rawat inap 
Tabel 4. Pengaruh variabel terhadap komplikasi pascaoperasi

\begin{tabular}{|c|c|c|c|c|c|c|}
\hline \multirow{2}{*}{ Variabel } & \multicolumn{3}{|c|}{ Komplikasi (n, \%) } & \multirow{2}{*}{ B } & \multirow{2}{*}{$\mathbf{p}$} & \multirow{2}{*}{$\begin{array}{c}\text { OR } \\
95 \% \mathrm{Cl}\end{array}$} \\
\hline & $\mathrm{Ya}$ & Tidak & Total & & & \\
\hline \multicolumn{7}{|l|}{ Albumin admisi } \\
\hline Hipoalbumin & $48(44,44)$ & $60(55,56)$ & 108 & $-0,749$ & $0,017^{*}$ & 2,116 \\
\hline Non-hipoalbumin & $25(23,15)$ & $83(76,85)$ & 108 & & & $(1,144-3,914)$ \\
\hline \multicolumn{7}{|l|}{ Albumin praoperasi } \\
\hline Hipoalbumin & $43(44,79)$ & $53(55,21)$ & 96 & 0,687 & $0,025^{\star}$ & 1,989 \\
\hline Non-hipoalbumin & $30(25,00)$ & $90(75,00)$ & 120 & & & $(1,089-3,632)$ \\
\hline \multicolumn{7}{|l|}{ Usia (tahun) } \\
\hline $20-59$ & $44(48,35)$ & $47(51,65)$ & 91 & 0,923 & $0,004^{*}$ & 2,518 \\
\hline$\geq 60$ & $29(23,20)$ & $96(76,80)$ & 125 & & & $(1,336-4,747)$ \\
\hline \multicolumn{7}{|l|}{ ASA } \\
\hline I - II & $39(28,47)$ & $98(71,53)$ & 137 & 0,224 & 0,495 & 1,251 \\
\hline III - IV & $34(43,04)$ & $45(56,96)$ & 79 & & & $(0,657-2,383)$ \\
\hline
\end{tabular}

Keterangan: * bermakna $(\mathrm{p}<0,05)$; ASA = American Society of Anesthesiologist Physical Status Classification

Tabel 5. Pengaruh variabel terhadap LOS total dan LOS pascaoperasi

\begin{tabular}{|c|c|c|c|c|c|c|c|c|c|c|}
\hline \multirow[b]{2}{*}{ Variabel } & \multicolumn{5}{|c|}{ LOS total } & \multicolumn{5}{|c|}{ LOS pascaoperasi } \\
\hline & $\begin{array}{c}\text { Panjang } \\
\text { n (\%) }\end{array}$ & $\begin{array}{c}\text { Pendek } \\
\mathrm{n}(\%) \\
\end{array}$ & B & $\mathbf{p}$ & OR (95\%Cl) & $\begin{array}{c}\text { Panjang } \\
\mathrm{n}(\%)\end{array}$ & $\begin{array}{c}\text { Pendek } \\
\text { n (\%) }\end{array}$ & B & $\mathbf{p}$ & OR $(95 \% \mathrm{Cl})$ \\
\hline \multicolumn{11}{|l|}{ Albumin admisi } \\
\hline Hipoalbumin & $91(84,26)$ & $17(15,74)$ & $-0,024$ & 0,951 & 0,976 & $66(61,11)$ & $42(38,89)$ & 0,209 & 0,470 & 1,233 \\
\hline Non-hipoalbumin & $91(84,26)$ & $17(15,74)$ & & & $(0,456-2,088)$ & $59(54,63)$ & $49(45,37)$ & & & $(0,699-2,175)$ \\
\hline \multicolumn{11}{|l|}{ Albumin praoperasi } \\
\hline Hipoalbumin & $81(84,38)$ & $15(15,63)$ & $-0,008$ & 0,982 & 0,991 & $61(63,54)$ & $35(36,46)$ & 0,371 & 0,201 & 1,449 \\
\hline Non-hipoalbumin & $101(84,17)$ & $19(15,83)$ & & & $(0,464-2,115)$ & $64(53,33)$ & $56(46,67)$ & & & $(0,820-2,560)$ \\
\hline \multicolumn{11}{|l|}{ Usia (tahun) } \\
\hline $20-59$ & $78(85,71)$ & $13(14,29)$ & 0,252 & 0,544 & 1,287 & $60(65,93)$ & $31(34,07)$ & 0,645 & $0,038^{*}$ & 1,907 \\
\hline$\geq 60$ & $104(83,20)$ & $21(16,8)$ & & & $(0,570-2,904)$ & $65(52,00)$ & $60(48,00)$ & & & $(1,037-3,505)$ \\
\hline \multicolumn{11}{|l|}{ ASA } \\
\hline I- II & $116(84,67)$ & $21(15,33)$ & $-0,163$ & 0,692 & 0,849 & $80(58,39)$ & $57(41,61)$ & $-0,301$ & 0,334 & 0,740 \\
\hline III - IV & $66(83,54)$ & $13(16,46)$ & & & $(0,378-1,905)$ & $45(56,96)$ & $34(43,04)$ & & & $(0,401-1,363)$ \\
\hline
\end{tabular}

Keterangan: * bermakna $(p<0,05) ;$ LOS $=$ length of stay /lama rawat inap

Hasil uji regresi logistik menunjukkan bahwa status kadar albumin admisi mempunyai pengaruh yang kuat $(B=-0,749 ; O R=2,116 ; 95 \% C l=1,144-3,914 ; p<0,05)$ terhadap kejadian komplikasi pascaoperasi. Pasien kanker kolorektal yang memiliki status hipoalbumin berdasarkan kadar albumin admisi mempunyai risiko 2,1 kali akan mengalami komplikasi pascaoperasi dibandingkan pasien kanker kolorektal yang memiliki status non-hipoalbumin. Demikian juga dengan status albumin berdasarkan kadar albumin praoperasi yang berpengaruh kuat $(B=0,687$; $\mathrm{OR}=1,989 ; 95 \% \mathrm{Cl}=1,089-3,632 ; \mathrm{p}<0,05)$ terhadap kejadian komplikasi pascaoperasi. Pasien kanker kolorektal yang memiliki status hipoalbumin berdasarkan kadar albumin praoperasi mempunyai risiko 1,9 kali akan mengalami komplikasi pascaoperasi dibandingkan pasien yang memiliki status non-hipoalbumin. Sementara itu, usia mempunyai pengaruh yang paling kuat $(B=0,923$; $\mathrm{OR}=2,518 ; 95 \% \mathrm{Cl}=1,336-4,747 ; \mathrm{p}<0,05)$ terhadap kejadian komplikasi pascaoperasi. Pasien kanker kolorektal yang berusia 20 sampai 59 tahun mempunyai risiko 2,5 kali akan mengalami komplikasi pascaoperasi dibandingkan pasien kanker kolorektal yang berusia lebih dari 60 tahun (Tabel 4).

Lebih lanjut, status kadar albumin berdasarkan kadar albumin admisi dan kadar albumin praoperasi tidak menunjukkan hubungan yang bermakna terhadap lama rawat inap total maupun lama rawat inap pascaoperasi. Demikian juga dengan variabel usia dan status ASA terhadap lama rawat inap total. Namun, status usia mempunyai pengaruh yang kuat $(B=0,645 ; O R=1,907$; $95 \% \mathrm{Cl}=1,037-3,505 ; \mathrm{p}<0,05)$ terhadap lama rawat inap pascaoperasi. Pasien kanker kolorektal yang berusia lebih dari 60 tahun mempunyai risiko 1,9 kali menjalani lama rawat inap pascaoperasi lebih panjang dibandingkan pasien kanker kolorektal yang berusia 20 sampai 59 tahun (Tabel 5). 


\section{BAHASAN}

\section{Komplikasi pascaoperasi}

Hasil analisis menunjukkan adanya hubungan usia terhadap kadar albumin admisi $(p=0,002)$ dan kadar albumin praoperasi $(p=0,003)$ serta status ASA terhadap kadar albumin admisi $(p=0,016)$. Lebih lanjut, analisa bivariat menunjukkan bahwa hipoalbumin berdasarkan status albumin admisi $(p=0,001)$ maupun status albumin praoperasi $(p=0,002)$ merupakan faktor risiko yang bermakna untuk terjadinya komplikasi pascaoperasi pasien kanker kolorektal. Demikian juga dengan faktor usia $(p=0,000)$ dan status ASA $(p=0,029)$. Hasil penelitian ini sejalan dengan penelitian di Thailand yang menyatakan adanya hubungan antara hipoalbumin dengan risiko terjadinya komplikasi pascaoperasi pada pasien kanker kolorektal $(p=0,034)(3)$.

Pasien kanker kolorektal yang memiliki status hipoalbumin berdasarkan kadar albumin admisi $(O R=2,116)$ dan kadar albumin praoperasi $(O R=1,989)$ menunjukkan adanya hubungan dengan kejadian komplikasi pascaoperasi. Hasil tersebut menunjukkan bahwa kemungkinan risiko terjadinya komplikasi pascaoperasi berdasarkan kadar albumin praoperasi hanya turun sebesar 0,2 kali dibandingkan dengan status albumin pasien kanker kolorektal berdasarkan kadar albumin admisi. Hal ini mungkin disebabkan oleh penatalaksanaan praoperasi untuk meningkatkan status albumin pasien kanker kolorektal kurang optimal.

Penelitian yang dilakukan di Pakistan menyatakan bahwa pasien kanker kolorektal yang memiliki status hipoalbumin (<3,5 g/dL) memiliki risiko 3,1 kali lebih besar untuk terjadinya komplikasi pascaoperasi tahap awal dibandingkan dengan status non-hipoalbumin $(\mathrm{OR}=3,107 ; 95 \% \mathrm{Cl}=1,18-8,15 ; \mathrm{p}=0,02)$ (14). Demikian juga penelitian yang dilakukan di RSUP Dr Sardjito Yogyakarta, membuktikan bahwa status gizi kurang memberikan peluang 4,8 kali lebih besar terjadinya penyembuhan luka tidak baik dibandingkan dengan status gizi baik (15).

Hasil analisis multivariat menunjukkan status hipoalbumin mempengaruhi kejadian komplikasi infeksi pascaoperasi pasien kanker kolorektal, baik berdasarkan status albumin admisi $(O R=2,098)$ maupun status albumin praoperasi $(\mathrm{OR}=1,885)$, tetapi tidak menunjukkan adanya pengaruh terhadap jenis komplikasi leakage, perdarahan, sepsis maupun kematian. Selain itu, hasil analisis multivariat yang menarik dari penelitian ini yaitu faktor usia 20 - 59 tahun mempunyai hubungan yang kuat terhadap kejadian infeksi pascaoperasi dibandingkan pasien kanker kolorektal yang berusia lebih dari 60 tahun $(\mathrm{OR}=2,089)$, tetapi tidak terhadap jenis komplikasi pascaoperasi yang lain. Hasil penelitian ini berbeda dengan beberapa penelitian sebelumnya yang menunjukkan pasien kanker kolorektal yang berusia lanjut memiliki risiko lebih tinggi untuk terjadinya komplikasi dibandingkan pasien kanker kolorektal yang berusia muda. Namun, penelitian di Jepang pada tahun 2011 mendukung hasil penelitian ini dengan membuktikan bahwa persentase kejadian komplikasi infeksi dan leakage pada kelompok pasien kanker kolorektal berusia lanjut tidak lebih tinggi secara bermakna, meskipun status gizi kelompok pasien kanker kolorektal yang berusia lanjut lebih buruk dibandingkan kelompok pasien kanker kolorektal usia muda. Dengan demikian, dapat ditarik kesimpulan bahwa hipoproteinemia dan hipoalbuminemia tidak mempengaruhi proses penyembuhan pascaoperasi kanker kolorektal (6). Faktor usia tidak mempengaruhi kejadian komplikasi leakage pascaoperasi kanker kolorektal pada kelompok usia lanjut maupun usia muda, meskipun kejadian komplikasi pascaoperasi lebih sering terjadi pada kelompok usia lanjut $(16,17)$. Usia bukan satu-satunya faktor risiko untuk timbulnya komplikasi terhadap pasien kanker kolorektal yang akan menjalani operasi. Sementara itu, faktor usia sendiri tidak seharusnya dijadikan alasan untuk menghindari terapi atau operasi, melainkan harus fokus terhadap kondisi klinis dan status ASA pasien kanker kolorektal (18).

Sementara itu, status ASA mempunyai pengaruh yang kuat hanya terhadap kejadian komplikasi sepsis pascaoperasi $(\mathrm{OR}=2,829 ; 95 \% \mathrm{Cl}=1,037-7,720 ; \mathrm{p}<0,05)$ dan kematian (OR=3,752; 95\%Cl=1,364-10,318; $p<0,05)$. Hasil penelitian ini sejalan dengan penelitian di Spanyol tahun 2010 yang membuktikan bahwa pasien kanker kolorektal dengan status ASA III - IV memiliki risiko 2,4 kali mengalami komplikasi kematian pascaoperasi dibandingkan pasien kanker kolorektal dengan status ASA I - II (OR=2,40; 95\%Cl=1,14-5,09; $p=0,021)$. Bahkan, pasien kanker kolorektal dengan status ASA lebih dari II memiliki risiko 2,9 kali terjadi komplikasi sistemik dibandingkan dengan pasien kanker kolorektal dengan status ASA kurang dari II (OR=2,86; 95\% Cl=1,30-6,25). Hasil penelitian di Turki juga menunjukkan bahwa status ASA merupakan faktor risiko yang bermakna untuk kejadian komplikasi kematian pascaoperasi $(\mathrm{OR}=12,13$; $95 \% \mathrm{Cl}=2,44-60,37)(14,19,20)$.

Menurut hasil analisis multivariat dalam penelitian yang dilakukan di Italia menyatakan faktor-faktor yang berhubungan dengan komplikasi pascaoperasi kanker gastrointestinal adalah operasi pankreas $(p<0,001)$, usia lanjut $(p=0,002)$, kehilangan berat badan $(p=0,019)$, kadar serum albumin rendah $(p=0,019)$, dan dukungan nutrisi $(p=0,001)(21)$. Selain itu, peningkatan angka kejadian komplikasi pascaoperasi secara bermakna dipengaruhi oleh jenis kelamin laki-laki, usia lebih dari 75 tahun, status ASA lebih dari atau sama dengan III, tingkat malignansi neoplasia, dan pengalaman dari dokter bedah (10). Beberapa penelitian terkini tidak hanya menggarisbawahi faktor usia dan penyakit ketika menjalani suatu tindakan operasi, tetapi juga membantu 
dalam menentukan risiko-risiko secara akurat, terutama faktor-faktor yang dimiliki seorang pasien seringkali memiliki keterkaitan yang kuat dengan kematian pasien daripada faktor-faktor tindakan operasi. Faktor-faktor praoperasi yang penting adalah usia, status ASA, kegawatan tindakan operasi, dan konsentrasi serum albumin (22). Mayoritas komplikasi yang timbul dalam tindakan operasi terhadap pasien kanker kolorektal usia lanjut tidak sepenuhnya karena pembedahan, tetapi lebih cenderung bersifat umum, baik pada pra dan pascaoperasi. Jika ditinjau lebih dalam lagi, kemungkinan diakibatkan oleh tidak optimalnya pada saat persiapan praoperasi (23).

\section{Lama rawat inap (length of stay)}

Komplikasi pascaoperasi sering diduga menjadi faktor utama yang bertanggungjawab terhadap lama rawat inap yang panjang. Bahkan, dalam salah satu penelitian menyatakan lama rawat inap akan menjadi 2 kali lebih lama pada pasien dengan komplikasi pascaoperasi. Selain itu, kadar albumin yang rendah juga berhubungan dengan memanjangnya lama rawat inap total di rumah sakit atau memanjangnya lama rawat inap pascaoperasi $(3,24)$. Hipoalbuminemia sangat berhubungan kuat terhadap hasil klinis yang buruk (25). Kadar serum albumin yang diukur pada hari pertama menjalani proses rawat inap merupakan alat untuk memperkirakan kejadian kematian di rumah sakit, infeksi nosokomial, dan lama rawat inap (26). Berbeda dengan hasil penelitian ini yang menunjukkan bahwa kadar serum albumin (kadar albumin admisi dan kadar albumin praoperasi) tidak memiliki hubungan dengan lama rawat inap total dan lama rawat inap pascaoperasi. Namun, jika dilihat dari rerata lama rawat inap menunjukkan bahwa pasien kanker kolorektal yang memiliki status hipoalbumin menjalani proses rawat inap lebih lama dibandingkan dengan pasien kanker kolorektal yang memiliki status albumin normal, baik dari rerata lama rawat inap total maupun lama rawat inap pascaoperasi. Selain itu, berdasarkan hasil analisis multivariat juga diperoleh kadar serum albumin (kadar albumin admisi dan kadar albumin praoperasi) yang tidak berpengaruh terhadap lama rawat inap total dan lama rawat inap pascaoperasi setelah dianalisis bersama dengan variabel lain.

Hasil penelitian sebelumnya menunjukkan bahwa faktor usia merupakan faktor luar yang berhubungan dan berpengaruh secara bermakna terhadap lama rawat inap pascaoperasi ( $p=<0,05$; $R R=1,907)$. Artinya, pasien kanker kolorektal yang berusia lebih dari 60 tahun mempunyai risiko 1,9 kali akan menjalani lama rawat inap pascaoperasi lebih panjang dibandingkan pasien kanker kolorektal yang berusia 20 sampai 59 tahun. Pasien usia lanjut memiliki risiko yang lebih tinggi terhadap komplikasi perioperatif dan kematian pascaoperasi non-kardiak dan lama rawat inap lebih panjang $(27,28)$. Sementara itu, penelitian di Australia membuktikan bahwa masa rawat inap yang memanjang pada pasien yang menjalani operasi memiliki hubungan dengan rendahnya kualitas perawatan praoperasi dan kondisi malnutrisi (29). Status gizi kurang pada pasien yang akan menjalani tindakan operasi dapat memberikan peluang 5,5 kali terjadinya lama rawat inap pascaoperasi panjang lebih dari 7 hari dibandingkan dengan status gizi baik (15). Malnutrisi berhubungan erat dengan peningkatan angka kesakitan dan kematian pascaoperasi mayor gastrointestinal. Pemberian nutrisi selama perioperatif dapat memperbaiki kelainan-kelainan biokimia dan imunologik pada kondisi malnutrisi atau normal $(30,31)$. Beberapa penelitian mengindikasikan penurunan angka kesakitan dan kematian secara bermakna berhubungan dengan pemberian nutrisi parenteral yang terbatas pada pasien kanker gastrointestinal yang mengalami malnutrisi berat. Bahkan, hasil penelitian meta-analisis menunjukkan pemberian nutrisi enteral berhubungan dengan penurunan kejadian komplikasi sepsis dibandingkan pemberian nutrisi parenteral, mengurangi biaya rumah sakit, dan mengurangi lama rawat inap sehingga nutrisi enteral sebisa mungkin menjadi pilihan yang utama (32).

Pemberian nutrisi selama perioperatif dapat menurunkan kejadian komplikasi pascaoperasi pasien kanker gastrointestinal. Pemberian nutrisi parenteral, nutrisi enteral atau kombinasi keduanya dapat digunakan terhadap penatalaksanaan pasien malnutrisi yang akan menjalani operasi gastrointestinal (30). Pemberian nutrisi enteral secara bermakna mengurangi komplikasi infeksi pascaoperasi dan lama rawat inap pasien kanker yang akan menjalani operasi (33). Pasien dengan status gizi yang buruk (misalnya penurunan berat badan dan hipoalbuminemia) harus diberikan terapi nutrisi selama 7 sampai 10 hari dan lebih baik diberikan dalam bentuk nutrisi enteral $(34,35)$. Berdasarkan kriteria dari European Society for Clinical Nutrition and Metabolism (ESPEN), disebutkan bahwa pasien walaupun tanpa keadaan kurang gizi, tetapi tidak dapat makan selama lebih dari 7 hari perioperatif dan pasien yang tidak dapat memenuhi kebutuhan asupan secara oral $(>60 \%)$ selama lebih dari 10 hari dianjurkan mendapatkan dukungan nutrisi (15). Pada penelitian ini menunjukkan bahwa rerata lama rawat inap praoperasi selama 4 hari. Hal ini menunjukkan bahwa terapi nutrisi yang diberikan belum adekuat dan dapat mempengaruhi kejadian komplikasi pascaoperasi.

Dukungan nutrisi merupakan terapi yang penting untuk pasien kanker kolorektal dan pemberian nutrisi yang tepat dan moderat dapat meningkatkan pemulihan pascaoperasi secara bermakna, mengurangi penderitaan pasien, dan mengurangi biaya medis pasien (35). Tim bedah juga harus memikirkan apa yang harus dilakukan untuk mengurangi kebutuhan akan ventilator pascaoperasi, mengurangi efek samping dari status gizi praoperasi 
yang buruk, luka infeksi pascaoperasi, penempatan stoma, komplikasi saluran kemih, dan kehilangan darah akibat operasi (24). Dengan penatalaksanaan medis dan pemberian nutrisi praoperasi yang optimal diharapkan dapat mengurangi risiko terjadinya komplikasi pascaoperasi dan memperpendek lama rawat inap pasien kanker kolorektal yang akan menjalani operasi elektif.

\section{SIMPULAN DAN SARAN}

Status hipoalbumin praoperasi mempengaruhi terjadinya komplikasi pascaoperasi terutama kejadian infeksi pada pasien kanker kolorektal yang akan menjalani operasi elektif. Faktor usia dan status ASA merupakan faktor luar yang paling berpengaruh terhadap kejadian komplikasi pascaoperasi dan lama rawat inap pascaoperasi pasien kanker kolorektal. Status hipoalbumin praoperasi tidak mempengaruhi lama rawat inap baik terhadap lama rawat inap total maupun lama rawat inap pascaoperasi pasien kanker kolorektal dan faktor usia merupakan faktor luar yang paling berpengaruh terhadap lama rawat inap pascaoperasi.

Tim asuhan gizi rumah sakit harus memberikan perhatian terhadap prinsip dan metode terapi gizi yang tepat dan menghindari pemberian terapi gizi yang kurang tepat tanpa melalui pemeriksaan status gizi terlebih dahulu. Pemberian terapi gizi di rumah sakit harus diberikan seoptimal mungkin sekaligus meningkatkan kualitas pelayanan medis dan pencegahan infeksi nosokomial kepada pasien kanker kolorektal yang akan menjalani operasi elektif agar meminimalkan risiko kejadian komplikasi pascaoperasi dan mempersingkat lama rawat inap di rumah sakit. Penelitian mengenai pengaruh serum albumin terhadap kejadian komplikasi pascaoperasi dan lama rawat inap terhadap pasien kanker kolorektal ini bisa ditindaklanjuti dengan penelitian yang bersifat prospektif eksperimental sehingga akan menghasilkan kesimpulan yang lebih baik.

\section{RUJUKAN}

1. Gupta D, Lis CG. Pretreatment serum albumin as a predictor of cancer survival: a systematic review of the epidemiological literature. Nutr J 2010;9:69.

2. Skibber JM, Minsky BD, Hoff PM. Cancer: principles and practice of oncology. $6^{\text {th }}$ edition. Devita VT Jr, Hellman S, Rosenberg SA, editors. Philadelphia, USA: Lippincott Williams \& Wilkins; 2001.

3. Lohsiriwat $\mathrm{V}$, Lohsiriwat D, Boonnuch $\mathrm{W}$, Chinswangwatanakul V, Akaraviputh T, Lertakayamanee N. Pre-operative hypoalbuminemia is a major risk factor for postoperative complications following rectal cancer surgery. World J Gastroenterol 2008;14(8):1248-51.
4. Fraser WD. Medical biochemistry: blood: cells and plasma proteins. $3^{\text {rd }}$ edition. Bayner JW, Dominiczack $\mathrm{MH}$, editors. Philadelphia: Elsevier Mosby; 2009.

5. Salvino RM, Dechicco RS, Seidner DL. Perioperative nutrition support: who and how. Cleve Clin J Med 2004;71(4):345-51.

6. Cohen DA. Neoplastic disease. In: Nelms M, Sucher K, Long S. Nutrition therapy and pathophysiology. Belmont, CA: Thomson/Brooks-Cole; 2007.

7. Jin L, Inoue $N$, Sato $N$, Matsumoto $S$, Kanno $H$, Hashimoto Y, Tasaki K, Sato K, Sato S, Kaneko K. Comparison between surgical outcomes of colorectal cancer in younger and elderly patients. World $\mathrm{J}$ Gastroenterol 2011;17(12):1642-8.

8. Lemeshow S, Hosmer Jr DW, Klar J, Lwanga SK. Besar sampel dalam penelitian kesehatan. Pramono D. 1997 (Alih bahasa). Yogyakarta: UGM Press; 1997.

9. Jacobs DS, DeMott WR, Oxley DK. Laboratory test handbook with disease index. $3^{\text {rd }}$ edition. Hudson, NY: Lexi Comp; 2004.

10. Kirchhoff P, Dincler S, Buchmann P. A multivariate analysis of potential risk factors for intra- and postoperative complications in 1316 elective laparoscopic colorectal procedures. Ann Surg 2008;248(2):259-65.

11. WHO - Ditjen Yanmed. Pelatihan panduan, teori, tehnik perencanaan rumah sakit. Jakarta: Direktorat Jenderal Pelayanan Medis, Departemen Kesehatan Republik Indonesia; 1996.

12. Linker CA. Current medical diagnosis $\&$ treatment. $49^{\text {th }}$ edition. McPhee SJ, Papadakis MA, editors. New York: The McGraw Hill Companies, Inc; 2010.

13. Fischer SP, Bader AM, Sweitzer BJ. Miller's anesthesia. $7^{\text {th }}$ edition. In: Miller RD, editors. Philadelphia: Churchill Livingstone Elsevier; 2010.

14. Khan MR, Bari H, Raza SA. Early postoperative outcome after curative colorectal cancer surgery. Singapore Med J 2011;52(3):195-200.

15. Susetyowati, lja M, Makhmudi A. Status gizi pasien bedah mayor preoperasi berpengaruh terhadap penyembuhan luka dan lama rawat inap pascaoperasi di RSUP Dr Sardjito Yogyakarta. Jurnal Gizi Klinik Indonesia 2010;7(1):1-7.

16. Walker KG, Bell SW, Richard MJ, Mehanna D, Den OF, Chapnis PH, Bokey EL. Anastomotic leakage is predictive of diminished survival after potentially curative resection for colorectal cancer. Ann Surg 2004;240(2):255-9.

17. Hermans E, van Schaik PM, Prins HA, Ernst MF, Dautzenberg PJL, Bosscha K. Outcome of colonic surgery in elderly patients with colon cancer. J Oncol 2010; 2010: 865908.

18. Khan MR, Bari H, Zafar SN, Raza SA. Impact of age on outcome after colorectal cancer surgery in the 
elderly - a developing country perspective. BMC Surg 2011;11:17.

19. Alustiza JE, Toral BC, Cimarras EC, Ramirez JAR, Ramos JDS, Mediavilla LR, Alcorta IA, Diez NP. Postoperative mortality risk factors in colorectal cancer: follow up of a cohort in specialised unit. Cir Esp 2010;87(2):101-7.

20. Ozogul YB, Ulas M, Ozer I, Ercan M, Gomceli I, Birol Bostanci E, Atalay F, Akoglu M. Short -term outcomes after surgery for colorectal cancer in Turkish patients aged 70 and above. Tur J Gastroenterol 2010;21(3):257-61.

21. Bozzeti F, Gianotti L, Braga M, Di Carlo V, Mariani L. Postoperative complications in gastrointestinal cancer patients: the joint role of the nutritional status and the nutritional support. Clin Nutr 2007;26(6):698-709.

22. Story DA. Postoperative mortality and complications. Best Pract Res Clin Anaesthesiol 2011;25(3):319-27.

23. Latkauskas T, Rudinskaite G, Kurtinaitis J, Janciauskiene R, Tamelis A, Saladzinskas Z, Pavalkis D. The impact of age on post-operative outcomes of colorectal cancer patients undergoing surgical treatment. BMC Cancer 2005;5:153.

24. Reddy KM, Meyer CER, Palazzo FF, Conaghan P, Blunt MC, Stebbings WSL, Leicester RJ, Cullen PT. Postoperative stay following colorectal surgery: a study of factors associated with prolonged hospital stay. Ann R Coll Surg Engl 2003;85(2):111-4.

25. Vincent JL, Dubois MJ, Navickis RJ, Wilkes MM. Hypoalbuminemia in acute illness: is there a rationale for intervention? a meta-analysis of cohort studies and controlled trials. Ann Surg 2003;237(3):319-34.

26. Delgado-Rodríguez M, Medina-Cuadros M, GómezOrtega A, Martínez-Gallego G, Mariscal-Ortiz M, Martinez-Gonzalez MA, Sillero-Arenas M. Cholesterol and serum albumin levels as predictors of cross infection, death and length of hospital stay. Arch Surg 2002;137(7):805-12.

27. Polanczyk CA, Marcantonio E, Goldman L, Rohde LE, Orav J, Mangione CM, Lee TH. Impact of age on perioperative complications and length of stay in patients undergoing noncardiac surgery. Ann Intern Med 2001;134(8):637-43.

28. Fontani A, Martellucci J, Civitelli S, Tanzini G. Outcome of surgical treatment of colorectal cancer in the elderly. Updates Surg 2011;63(4):233-7.

29. Laky B, Janda M, Chennakesavan SK, Cleghorn G, Obermair A. Pretreatment malnutrition and quality of life - association with prolonged length of hospital stay among patients with gynecological cancer: a cohort study. BMC Cancer 2010;10:232.

30. Wu GH, Liu ZH, Wu ZH, Wu ZG. Perioperative artificial nutrition in malnourished gastrointestinal cancer patients. World J Gastroenterol 2006;12(15):2441-4.

31. Gomez Sanchez MB, Garcia-Talavera Espin NV, Sanchez Alvarez C, Zomeno Ros Al, Hernandez MN, Gomez Ramos MJ, Parra Banos P, Gonzalez Valverde FM. Perioperative nutritional support in patients with colorectal neoplasms. Nutr Hosp 2010;25(5):797-805.

32. Ward N. Nutrition support to patients undergoing gastrointestinal surgery. Nutr J 2003;2:18

33. Braga M, Gianotti L, Radaelli G, Vignali A, Mari G, Gentilini O, Di Carlo V. Perioperative immunonutrition in patients undergoing cancer surgery. Arch Surg 1999;134(4):428-33.

34. McClave SA, Snider HL, Spain DA. Preoperative issues in clinical nutrition. Chest 1999;115(5 Suppl):64S$70 S$.

35. Chen Y, Liu BL, Shang B, Chen AS, Liu SQ, Sun W, Yin $H Z$, Yin JQ, Su Q. Nutrition support in surgical patients with colorectal cancer. World J Gastroenterol 2011;17(13):1779-86. 